Article

\title{
The Role of Weather Types in Assessing the Rainfall Key Factors for Erosion in Two Different Climatic Regions
}

\author{
María Fernández-Raga ${ }^{1, *}$, Roberto Fraile ${ }^{1} \mathbb{D}$, Covadonga Palencia ${ }^{1} \mathbb{D}$, Elena $\operatorname{Marcos}^{2} \mathbb{D}$, \\ Ana María Castañón ${ }^{3}$ and Amaya Castro ${ }^{1}$ \\ 1 Department of Physics, IMARENAB, University of Leon, 24071 León, Spain; rfral@unileon.es (R.F.); \\ c.palencia@unileon.es (C.P.); acasi@unileon.es (A.C.) \\ 2 Department of Biodiversity and Environmental Management, University of Leon, 24071 León, Spain; \\ elena.marcos@unileon.es \\ 3 Department of Mining, University of Leon, 24071 León, Spain; amcasg@unileon.es \\ * Correspondence: maria.raga@unileon.es; Tel.: +34-987291000 (ext. 5342)
}

Received: 3 April 2020; Accepted: 26 April 2020; Published: 28 April 2020

\begin{abstract}
This paper compares two different geographical sites, Aveiro and León, from different climatic regions, oceanic and continental, but which share the same type of weather (according to Lamb's classification). The analysis was carried out over one year, and has revealed that rainfall in Aveiro is heavier and more abundant, with a higher number of raindrops and a longer duration of rain events (on average, 10 min longer than in Leon). Mean raindrop size is $0.45 \mathrm{~mm}$ in Aveiro and slightly smaller $(0.37 \mathrm{~mm})$ in Leon; in addition, the kinetic energy and linear momentum values in Aveiro are three times higher than those in Leon. A comparison of raindrop size distributions by weather type has shown that for both locations westerly weather presented a higher probability of rainfall, and the gamma distribution parameters for each weather type were independent of the study zone. When the analysis is done for the characteristics of rain related with erosion, the westerly cyclonic weather types (cyclonic west (CW) and cyclonic south-westerly (CSW)) are among the most energetic ones in both locations. However, comparing their five weather types with higher kinetic energy, in Aveiro a westerly component implies higher kinetic energy, while in Leon a southerly component involves more energy in the rain.
\end{abstract}

Keywords: weather types; disdrometer; rainfall precipitation; duration of rain events; raindrop size distribution

\section{Introduction}

In the Mediterranean area there is a relationship between atmospheric patterns like weather types (WTs) and other natural effects, like dispersion of aerosols [1], wildfires [2] or rainfall characterization [3]. The present study claims that WT studies may be relevant in an analysis of erosive parameters caused by rain.

The amount of rainfall registered in the Iberian Peninsula varies considerably depending on the region, due to the rugged terrain [4] and the influence of the Atlantic Ocean on the western side of the Peninsula $[5,6]$. This ocean is the source of most synoptic disturbances in the Peninsula $[7,8]$ and exerts a considerable influence on peninsular rainfall [9-11]. The influence of the Atlantic Ocean affects not only the number but also the size of raindrops, and this in turn affects other aspects as diverse as the erosive power of the raindrops [12-14] or radio wave propagation [15]. The use of disdrometers or other similar devices to detect the size and velocity of raindrops is therefore of considerable interest in 
order to measure variables such as the kinetic energy and momentum registered during a particular rain event [16-18].

As a result of the importance of assessing the influence of the ocean on the behavior of rainfall in different climates in neighboring regions or regions with similar characteristics [19-22], the aim of the present study is to compare the characteristics of rainfall in two points located only $230 \mathrm{~km}$ apart as regards east to west longitude, and $330 \mathrm{~km}$ in a straight line, but whose climates are very different. Aveiro has an oceanic sub-Mediterranean climate [23] and is located $28 \mathrm{~km}$ inland from the Atlantic Ocean, whereas Leon has a continental Mediterranean climate with Atlantic influences [24] and is located $358 \mathrm{~km}$ from the ocean. Nevertheless, due to their proximity, both sites share the same weather type according to Lamb's classification.

Therefore, this research may become a progress in the idea of using weather types as a possibility to simplify the measurement of rainfall parameters in erosion models, due to the simplicity of its calculation and the great number of uses that weather types already have in the modelization of other natural effects. If this analysis shows similar behavior of rain in places under the same weather type, it will be possible to try to use weather type classification in the analysis of erosion in larger areas, with the consequent decrease in the need of meteorological instrumental like disdrometers. For doing so, it will be necessary to prove that the characteristics of the rain related with rainfall erosivity under the same weather type are similar. Therefore, we have taken two places classified under the same weather type to explore these possibilities.

The hypothesis that we want to test in this study is to determine whether the rainfall characteristics that define erosion in two Iberian locations, Aveiro and Leon, with the same weather type but belonging to two different climatic regions, are similar. More specifically, for each of the 26 weather types, the goal is to determine whether the rainfall erosion-related parameters (such as duration of rain events, number of drops, raindrop size, accumulated precipitation or kinetic energy) are similar in both measurement sites. To do this, we have designed a methodology based in comparison of the most related parameters with erosion, adapting the methodology using disdrometers designed in Fernandez-Raga et al. [25] for the first time to compare two places.

\section{Experiments}

The first study zone was the city of Leon (province of Leon), located in the region of Castile and Leon in north-western Spain (Figure 1). This is a transition zone between the two main climatic regions in Spain: the Continental and the Mediterranean regions. There is frost in winter, but only in the early morning, and some rainfall, while summers are hot and dry. Rainfall is irregular throughout the year. The rainfall data were gathered at the University of Leon $\left(42^{\circ} 46^{\prime} \mathrm{N}, 5^{\circ} 35^{\prime} \mathrm{W}\right)$, located at about $840 \mathrm{~m}$ above sea level. The annual rainfall registered in Leon is $556 \mathrm{~mm}$ and average temperatures are around $10.9^{\circ} \mathrm{C}$, between $3.2^{\circ} \mathrm{C}$ in January and $19.3^{\circ} \mathrm{C}$ in August $[26,27]$.

At the second study zone, the rainfall data were gathered in a municipality in the District of Aveiro, Portugal, called Sever do Vouga. This location will be referred to as Aveiro, and is located $28 \mathrm{~km}$ inland from the coast $\left(40^{\circ} 40^{\prime} 49^{\prime \prime} \mathrm{N}\right.$ and $\left.8^{\circ} 20^{\prime} 35^{\prime \prime} \mathrm{W}\right)$, in the west of the Iberian Peninsula. It has a sub-Mediterranean oceanic climate, characterized by mild winters and summers. The Atlantic Ocean exerts considerable influence on this area, with strong winds and moist air masses that frequently cause heavy rainfall events. Temperatures range from $6.2^{\circ} \mathrm{C}$ in January to $19.3{ }^{\circ} \mathrm{C}$ in August [28]. The annual rainfall at this station is about $1880 \mathrm{~mm}$.

The sampling period extended from 1 May 2007 to 26 July 2008. To characterize and quantify rainfall at each study site, an optical disdrometer (THIES Laser Precipitation Monitor, LPM) and a Weather Link station were installed. The LPM measures every minute the falling velocity and the size of the raindrops crossing a sample area of $228 \times 20 \mathrm{~mm}^{2}$ by means of a laser beam with a wavelength of $780 \mathrm{~nm}$. Drop sizes are classified into 22 size bins, from 0.125 to $8 \mathrm{~mm}$. Fernandez-Raga et al. [29] provide a detailed description of the LPM. There has been no missing data in the time series. 
We have also studied the duration of rain events and the relationship between the rainfall registered and Lamb's classification of weather types. The weather type classification employed was described by Trigo and Dacamara [30] and requires information on direction and vorticity of the geostrophic flow obtained using the atmospheric pressure data at the 16 grid points [31]. This is an adaptation to the Iberian Peninsula of the widely used objective classification [32] designed by Lamb [33] and defined for the British Isles by Jenkinson and Collison [34]. The classification defines 26 different types of daily weather (Table 1), using a 16-point grid where pressure at sea level is known. The calculations for the different circulation parameters have been described in previous works [6,30,31]. The rainfall in Iberia has a monthly variability, which has already been studied $[9,35]$; the present study has been designed on a daily basis.

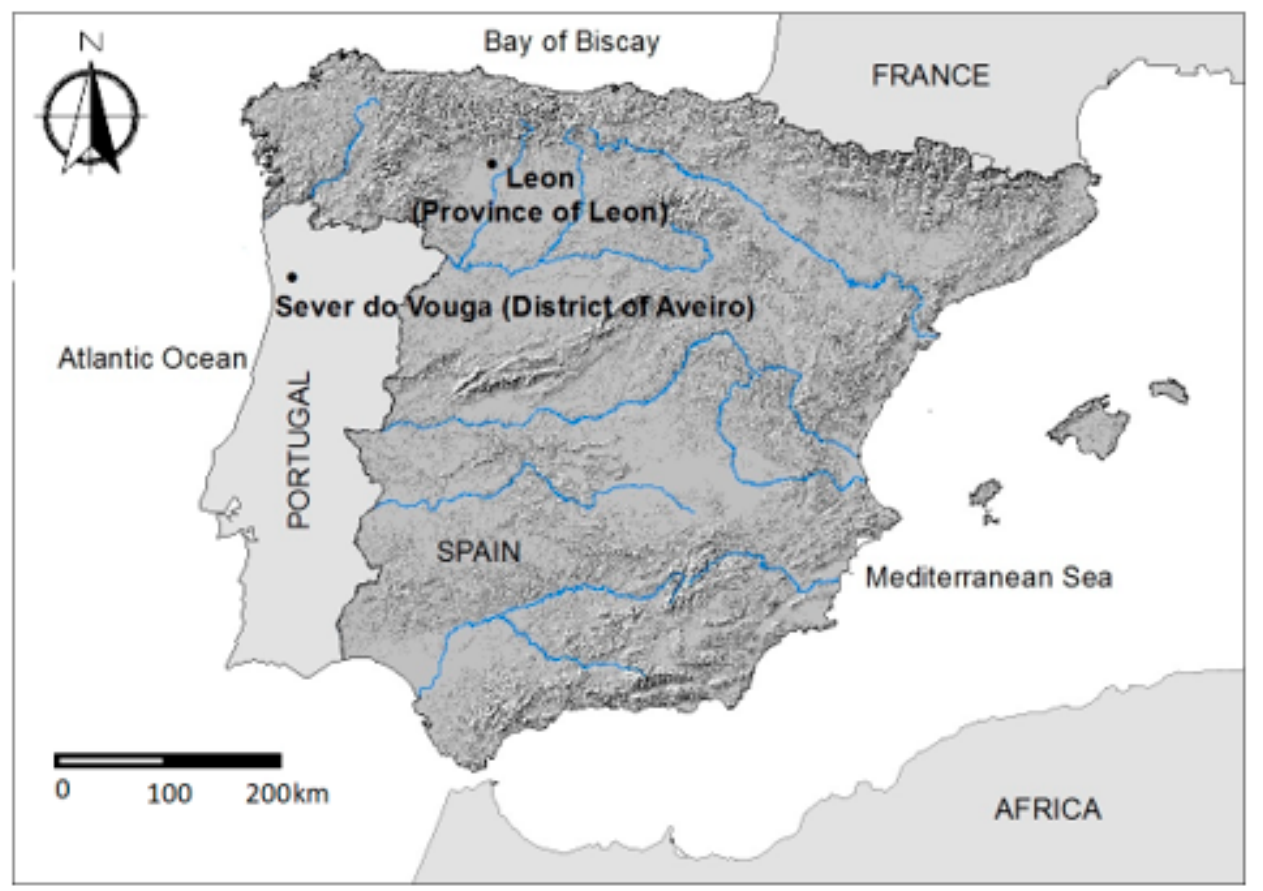

Figure 1. Location of disdrometers and weather stations at Sever do Vouga (district of Aveiro, Portugal) and Leon (province of Leon, Spain).

Table 1. Original weather types CWTs (Circulation Weather Types), including 8 directional types, 16 hybrid types and 2 additional types controlled by geostrophic vorticity (A and C) (Source: 30 ).

\begin{tabular}{|c|c|c|c|c|c|}
\hline \multicolumn{6}{|c|}{ Lamb's Weather Types } \\
\hline \multicolumn{2}{|r|}{ Anticyclonic } & \multicolumn{2}{|c|}{ Directional or Pure Types } & \multicolumn{2}{|r|}{ Cyclonic } \\
\hline $\mathrm{A}$ & anticyclonic & & & $\mathrm{C}$ & cyclonic \\
\hline ANE & anticyclonic-northeasterly & $\mathrm{NE}$ & northeasterly & $\mathrm{CNE}$ & cyclonic-northeasterly \\
\hline $\mathrm{AE}$ & anticyclonic-easterly & $\mathrm{E}$ & easterly & $\mathrm{CE}$ & cyclonic-easterly \\
\hline ASE & anticyclonic-southeasterly & SE & southeasterly & CSE & cyclonic-southwesterly \\
\hline AS & anticyclonic-southerly & $\mathrm{S}$ & southerly & $\mathrm{CS}$ & cyclonic-southerly \\
\hline ASW & anticyclonic-southwesterly & SW & southwesterly & CSW & cyclonic-southwesterly \\
\hline AW & anticyclonic-westerly & $\mathrm{W}$ & westerly & $\mathrm{CW}$ & cyclonic-westerly \\
\hline ANW & anticyclonic-northwesterly & NW & northwesterly & $\mathrm{CNW}$ & cyclonic-northwesterly \\
\hline $\mathrm{AN}$ & anticyclonic-northerly & $\mathrm{N}$ & northerly & $\mathrm{CN}$ & cyclonic-northerly \\
\hline
\end{tabular}

Probability density functions have been used to compare raindrop size distributions and rainfall volume distributions in Leon and Aveiro. Exponential and gamma distributions presented the best fit with our data [36,37].

Gamma distribution depends on the parameter $\alpha$. We have an exponential distribution when $\alpha=1$. Distribution also varies with the scale parameter $\beta$, which is related to the speed with which the 
curve falls to zero. The function is defined for any non-negative value of $x$, and parameters $\alpha$ and $\beta$ must be true positives. When $\alpha$ is $>1$, the gamma distribution is bell-shaped, with a maximum at $(\alpha-1) / \beta$. The moments method was used to determine the values of $\alpha$ and $\beta$ [38]. The moments method used the first two moments (mean $\mu$ and variance $\sigma^{2}$ ) of the distribution to correspond with the first two moments of the data series. With these data, the parameters of the distribution were calculated, using the following expressions: the value of the mean is $\mu=\alpha / \beta$ and the variance $\sigma^{2}=\alpha / \beta^{2}$.

\section{Results and Discussions}

\subsection{General Rainfall Characteristics}

Rain events were considered to have ended when less than $0.001 \mathrm{~mm}$ of rain were registered for a continuous period of $20 \mathrm{~min}$. Based on this assumption, the number of rain events recorded during the study period was $22 \%$ higher in Aveiro, with 313 events, than in Leon, with 245 . In addition, the mean duration of rainfall events was $10 \mathrm{~min}$ longer in Aveiro: $66 \mathrm{~min}$, compared to $56 \mathrm{~min}$ in Leon (Table 2). In Leon, the gamma probability density function calculated for event duration yielded a parameter $\alpha$ of 0.8 (close to 1), indicating a close fit with an exponential distribution function. In contrast, the parameter $\alpha$ for Aveiro was 0.52, thus not fitting an exponential distribution, since the maximum of the function would shift to positive values [39].

Table 2. Number of rain events recorded between 1 May 2007 and 26 July 2008, mean duration, percentage of events by duration and values for $\alpha$ and $\beta$ parameters of the gamma distribution function.

\begin{tabular}{|c|c|c|c|c|c|c|c|c|}
\hline \multirow[b]{2}{*}{ Site } & \multirow{2}{*}{$\begin{array}{c}\text { Number of } \\
\text { Complete Events } \\
\text { Detected }\end{array}$} & \multirow{2}{*}{$\begin{array}{c}\text { Average } \\
\text { Duration } \\
\text { (min) }\end{array}$} & \multicolumn{4}{|c|}{$\begin{array}{c}\text { Percentage of Events According to } \\
\text { Their Duration }\end{array}$} & \multicolumn{2}{|c|}{ Gamma Distribution } \\
\hline & & & $<20$ & \multicolumn{2}{|c|}{$(\min )$} & $>60$ & Alfa & $\begin{array}{c}\text { Beta } \\
\left(\min ^{-1}\right)\end{array}$ \\
\hline Aveiro & 313 & 66 & $46 \%$ & $19 \%$ & $10 \%$ & $25 \%$ & 0.523 & 0.0080 \\
\hline Leon & 245 & 56 & $46 \%$ & $20 \%$ & $12 \%$ & $22 \%$ & 0.806 & 0.0144 \\
\hline
\end{tabular}

Values for the scale parameter $\beta$ were similar, indicating that the frequency distribution of the duration presented a similar fall in both locations.

An analysis of daily rainfall volume revealed that Aveiro had a higher number of days than Leon for all the classes of rainfall registered, except for rainfall of less than $15 \mathrm{~mm}$ a day. In fact, of the 401 days compared, there were 350 days with less than $10 \mathrm{~mm}$ in Aveiro and 382 in Leon. Interestingly, only Aveiro, near the Atlantic Ocean, had six days where more than $25 \mathrm{~mm}$ fell in total, including one day that exceeded $55 \mathrm{~mm}$ (Figure 2).

In contrast, Leon lies in a more continental region and the maximum rainfall registered was $25 \mathrm{~mm}$ over 3 days. For $89 \%$ of days in Leon, rainfall did not exceed $5 \mathrm{~mm}$, whereas this percentage fell to $84 \%$ of days in Aveiro.

The mean rainfall intensity in Aveiro was $2.78 \mathrm{~mm} \mathrm{~h}^{-1}$, representing $65 \%$ more than the mean intensity in Leon (with $1.66 \mathrm{~mm} \mathrm{~h}^{-1}$ ), and $44 \%$ more in the case of maximum rainfall intensity (Table 3). The mean raindrop size was 20\% larger in Aveiro than in Leon; however, the maximum raindrop size was the same in both locations. An analysis of the kinetic energy and momentum indicated that the values in Aveiro were 1.7 and 3.7 times higher, respectively, than those in Leon (Table 3). Cumulative rainfall was $3.25 \mathrm{~mm}$ in Aveiro, more than twice the figure of $1.28 \mathrm{~mm}$ registered in Leon. 


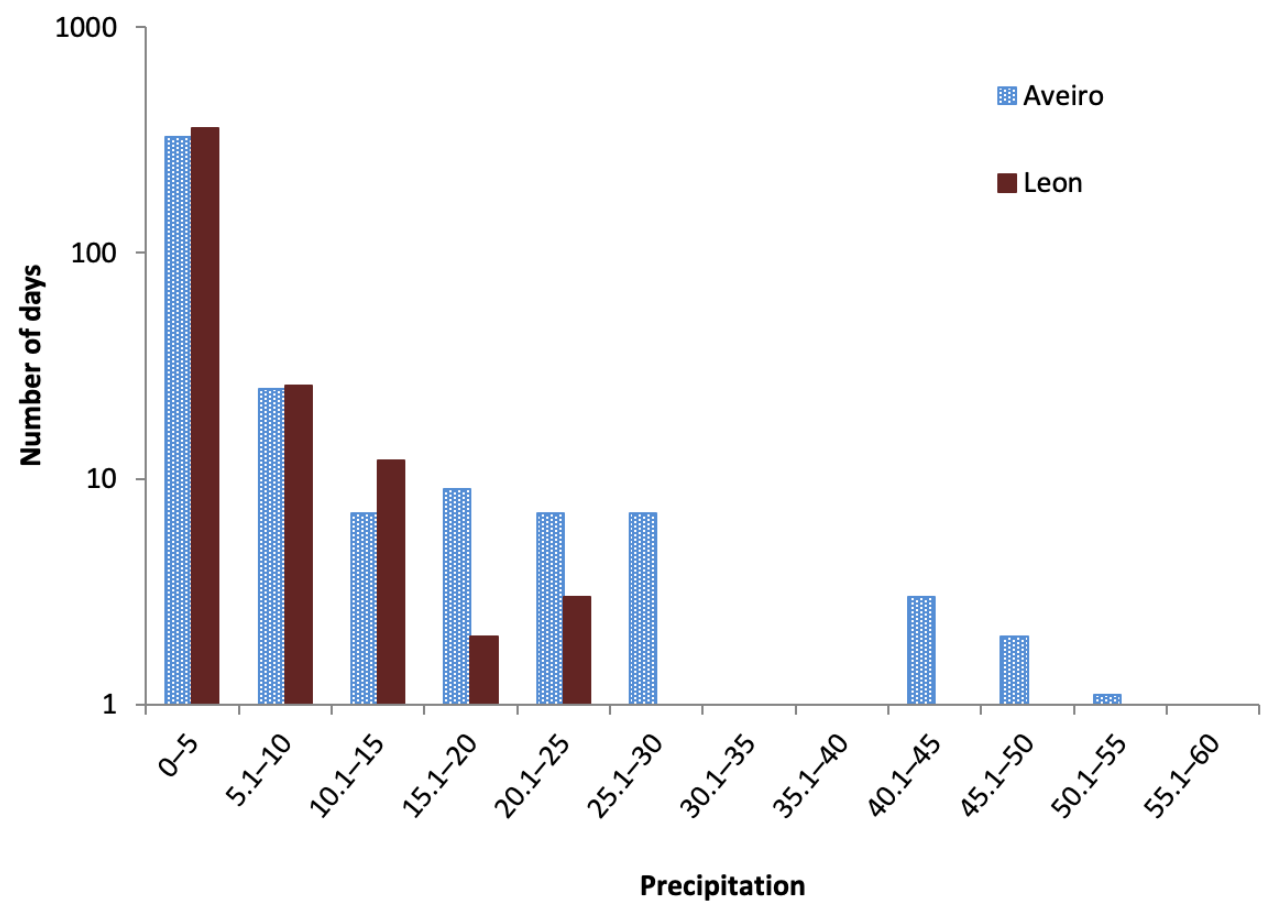

Figure 2. Frequency of daily rainfall volume registered in Aveiro, Portugal, and Leon, Spain.

Table 3. Daily values for characteristic rainfall parameters in León, Spain, and Aveiro, Portugal.

\begin{tabular}{|c|c|c|c|c|c|c|}
\hline \multirow[b]{2}{*}{ Characteristics of Rainfall Parameters } & \multicolumn{2}{|c|}{ Aveiro } & \multicolumn{2}{|c|}{ León } & \multirow{2}{*}{$\begin{array}{c}\text { Aveiro } \\
\text { Total } \\
\text { Sample }\end{array}$} & \multirow{2}{*}{$\begin{array}{c}\text { León } \\
\text { Total } \\
\text { Sample }\end{array}$} \\
\hline & Average & Maximum & Average & Maximum & & \\
\hline $\mathrm{N}$ of drops $\left(\mathrm{m}^{-2}\right)$ & $2.9 \times 10^{7}$ & $1.3 \times 10^{9}$ & $9.9 \times 10^{6}$ & $2.9 \times 10^{8}$ & $1.03 \times 10^{10}$ & $3.35 \times 10^{9}$ \\
\hline Drop size (mm) & 0.45 & 7.75 & 0.37 & 7.75 & & \\
\hline Cumulative precipitation (mm) & 3.25 & 55.8 & 1.28 & 25.7 & $1.14 \times 10^{3}$ & 582 \\
\hline Intensity of precipitation $\left(\mathrm{mm} \cdot \mathrm{h}^{-1}\right)$ & 2.78 & 119 & 1.66 & 82 & & \\
\hline Kinetic energy per unit area $\left(\mathrm{J} \cdot \mathrm{m}^{-2} \cdot \mathrm{mm}^{-1}\right)$ & 0.24 & 58.9 & 0.14 & 52 & $1.57 \times 10^{4}$ & $9.54 \times 10^{3}$ \\
\hline Momentum $\left(\mathrm{kg} \cdot \mathrm{m}^{-2} \cdot \mathrm{s}^{-1} \cdot \mathrm{mm}^{-1}\right)$ & 870 & 2464 & 452 & 1223 & $8.84 \times 10^{3}$ & $3.02 \times 10^{3}$ \\
\hline Reflectivity $\left(\mathrm{mm}^{6} \cdot \mathrm{m}^{-3}\right)$ & $3.16 \times 10^{3}$ & $1.77 \times 10^{6}$ & $4.23 \times 10^{3}$ & $1.49 \times 10^{6}$ & & \\
\hline Lambda $\left(\mathrm{mm}^{-1}\right)$ & 2.63 & 4.8 & 3.49 & 7.11 & & \\
\hline
\end{tabular}

Throughout the study period, the daily amount of rainfall and the daily number of raindrops per unit area were both higher in Aveiro than in Leon. Furthermore, a comparison between the cumulative daily rainfall in Aveiro and Leon revealed a linear relationship with a positive slope of 0.1687 between the daily amount of rainfall in Aveiro and Leon. When this comparison was repeated for the daily number of raindrops in Aveiro on the $x$-axis versus the number of raindrops in Leon on the $y$-axis, the slope was somewhat lower: 0.1466 . This finding coincides with the higher rainfall in an oceanic region versus the Mediterranean transition described by Gonzalez-Pola [40]. This also ties in with the fact that the mean raindrop size was slightly higher (and thus contained more water) in Aveiro than in Leon.

Interestingly, on the three days with most rainfall in Leon, the 21 and 24 May 2007 and the 24 October 2007, there was virtually no rain in Aveiro.

\subsection{Raindrop Spectrum, Kinetic Energy and Linear Momentum}

The mean raindrop size in Aveiro over the study period was around $0.45 \mathrm{~mm}$, whereas raindrops were smaller in Leon, with a mean size of $0.37 \mathrm{~mm}$. Some authors have claimed that raindrop size, mainly the number of the largest raindrops in raindrop size distribution (known as tail behavior), has an enormous influence on the main hydrology and meteorology parameters such as rain rate, 
liquid water content, radar reflectivity and kinetic energy [41]. In the locations studied, most raindrops ranged between $0.3 \mathrm{~mm}$ and $3 \mathrm{~mm}$ in diameter (Figure 3).

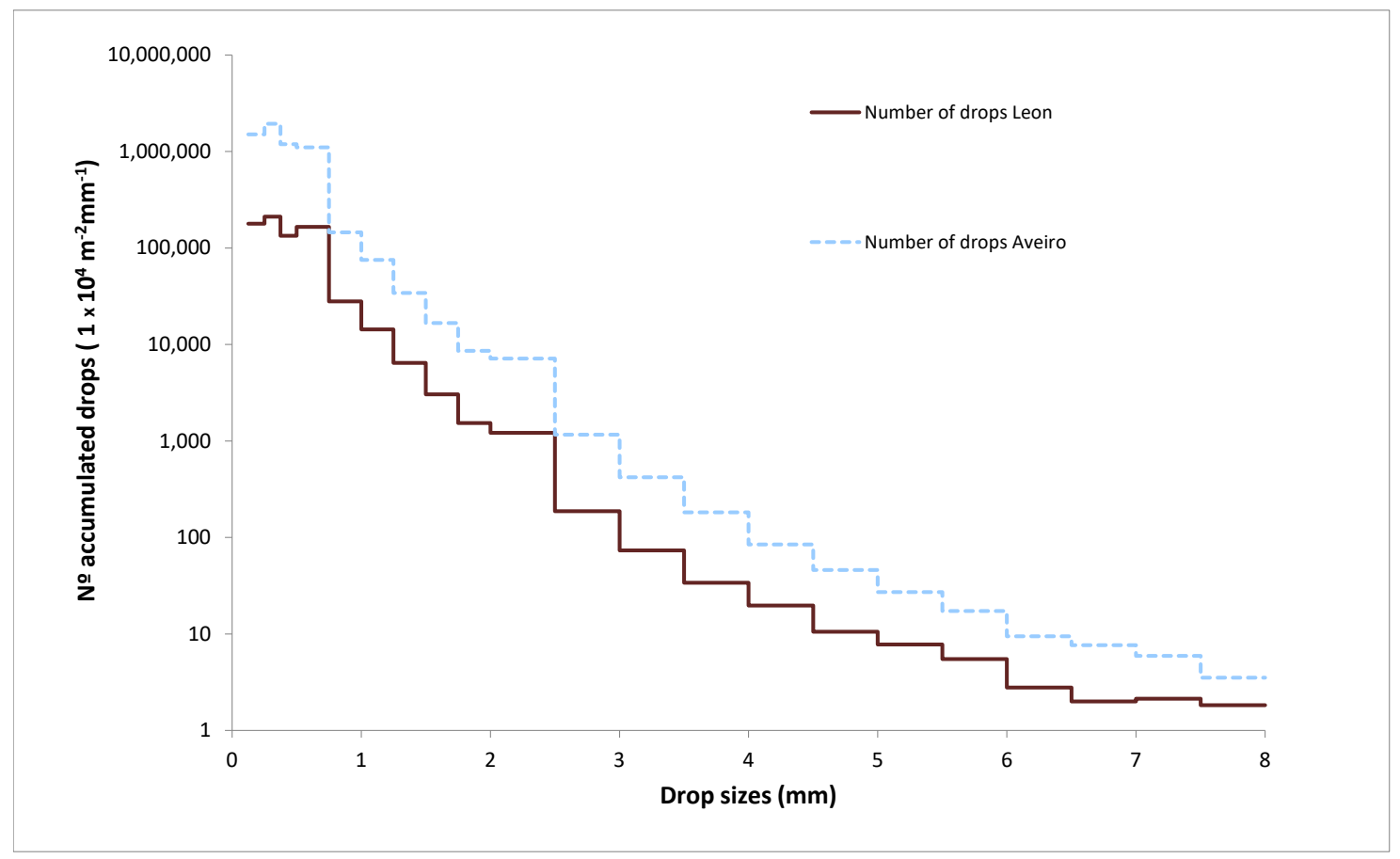

Figure 3. Spectrum of raindrops sizes recorded in Leon, Spain, and Aveiro, Portugal.

The data obtained from raindrop size and velocity measurements revealed a similar spectrum for both linear momentum and kinetic energy calculations. Since in both cases Aveiro had a higher number of raindrops per unit area and larger raindrops, rainfall in Aveiro will generate impacts with greater kinetic energy. A comparison of linear momentum or amount of movement between Aveiro and Leon (Figure 4) revealed spectra with magnitudes that were twice as high in Aveiro for all raindrop sizes. For example, the maximum linear momentum value corresponded to raindrops measuring between 1 and $1.25 \mathrm{~mm}$, reaching a value of $2.46 \times 10^{3} \mathrm{~kg} \cdot \mathrm{s}^{-1} \cdot \mathrm{m}^{-1} \cdot \mathrm{mm}^{-1}$ in Aveiro, whereas this was $1.22 \times 10^{3} \mathrm{~kg} \cdot \mathrm{s}^{-1} \cdot \mathrm{m}^{-1} \cdot \mathrm{mm}^{-1}$ in Leon (Figure 4). This spectrum remained very similar for kinetic energy (Figure 5), although the mode shifted slightly towards somewhat larger raindrops, with diameters ranging between 1.5 and $1.75 \mathrm{~mm}$. The kinetic energy registered in Aveiro was $6.11 \times 10^{3} \mathrm{~J} \cdot \mathrm{m}^{-2} \cdot \mathrm{mm}^{-1}$, more than twice the kinetic energy registered in Leon, with $2.96 \times 10^{3} \mathrm{~J} \cdot \mathrm{m}^{-2} \cdot \mathrm{mm}^{-1}$. These values are in the range of the $1170 \mathrm{~J} \cdot \mathrm{m}^{-2} \cdot \mathrm{mm}^{-1}$ maximum recorded in Zaragoza, Spain, by Angulo et al. [12].

With respect to the raindrop size spectrum, Figure 3 shows that in both Leon and Aveiro the number of raindrops decreased as the size increased, although Aveiro always had a higher number of raindrops.

The highest number of raindrops corresponded to channel 2 (Figure 6), with sizes ranging between 0.125 and $0.250 \mathrm{~mm}$. However, the channel yielding the greatest kinetic energy was unquestionably that of sizes ranging between 1.5 and $1.75 \mathrm{~mm}$ [31]. 


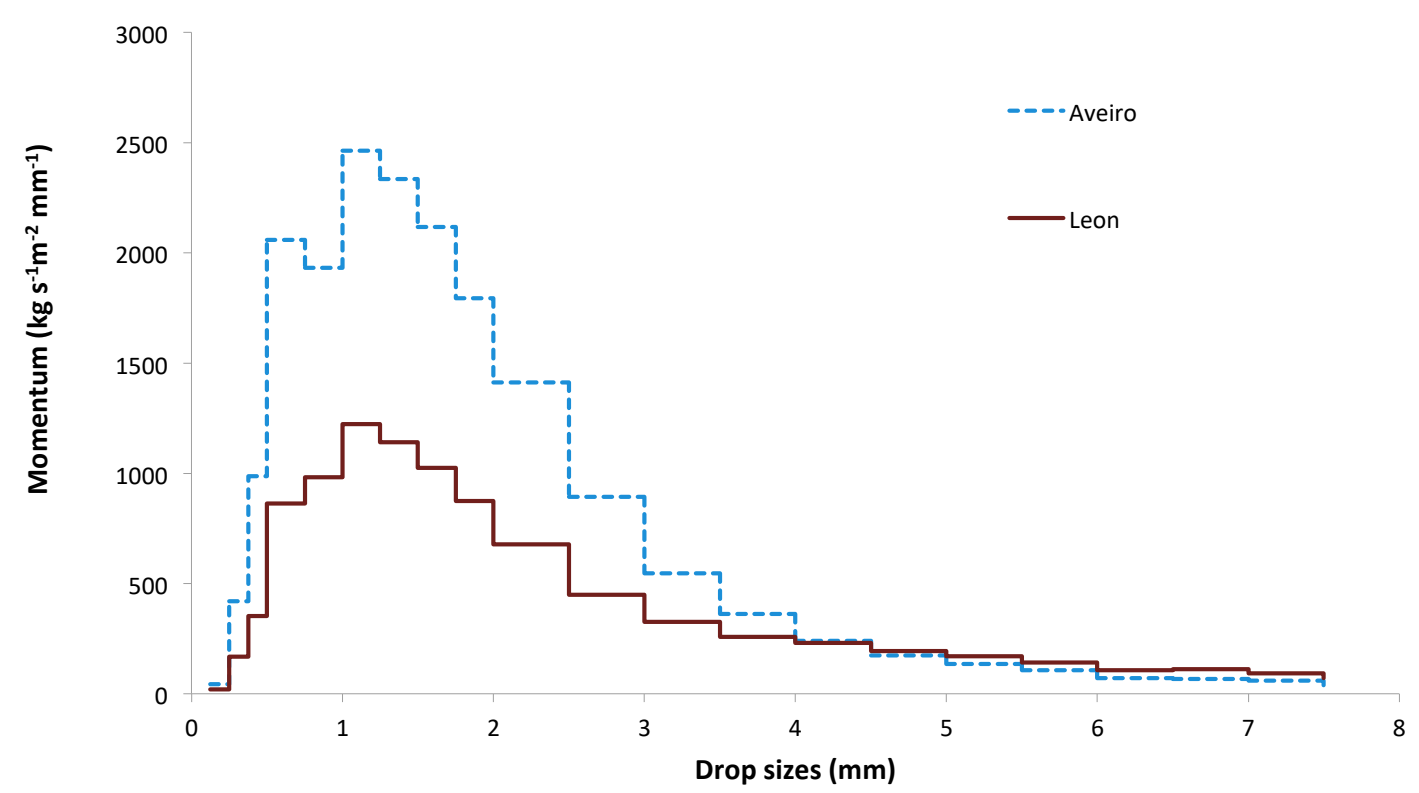

Figure 4. Cumulative linear momentum per unit area in Aveiro, Portugal, and Leon, Spain.

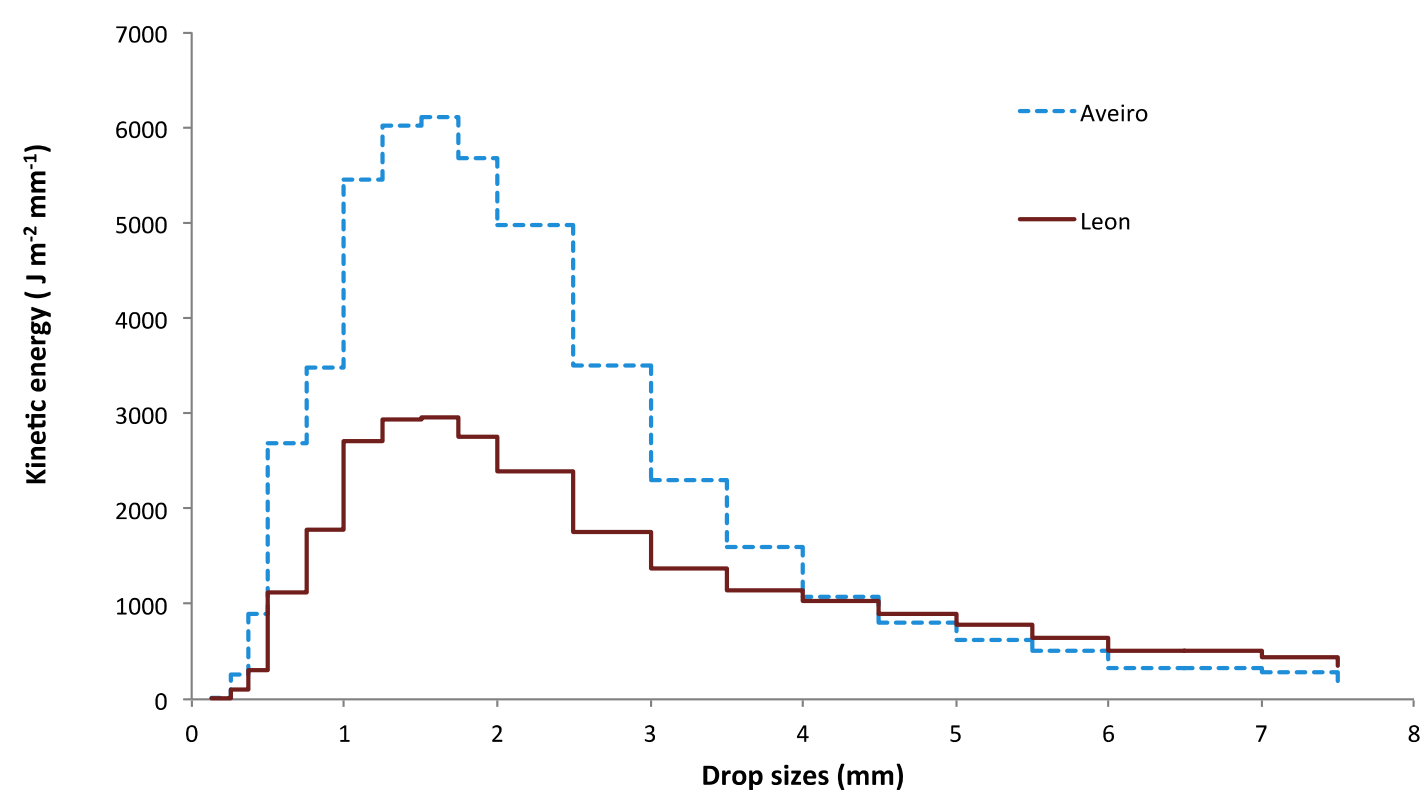

Figure 5. Cumulative kinetic energy per unit area in Aveiro and Leon.

The maximum kinetic energy value recorded in Aveiro in one minute was $58.9 \mathrm{~J} \cdot \mathrm{m}^{-2} \cdot \mathrm{mm}^{-1}$, and in Leon $52.0 \mathrm{~J} \cdot \mathrm{m}^{-2} \cdot \mathrm{mm}^{-1}$ (Table 3). These values are similar to those recorded in heavy rain events in Colombia [42], at $52.7 \mathrm{~J} \cdot \mathrm{m}^{-2} \cdot \mathrm{mm}^{-1}$ per minute, and Spain, at 64.99 in Javea (Alicante) in 1957 [43]. However, these values are not always so high. Van Dijk et al. [44] have reported values of $26.4 \mathrm{~J} \cdot \mathrm{m}^{-2} \cdot \mathrm{mm}^{-1}$ on the east coast of Australia, $35.9 \mathrm{~J} \cdot \mathrm{m}^{-2} \cdot \mathrm{mm}^{-1}$ in the south of Portugal and $33.6 \mathrm{~J} \cdot \mathrm{m}^{-2} \cdot \mathrm{mm}^{-1}$ in Arizona. Some authors have even estimated that with much lower kinetic energy values, simulated rainfall may be sufficiently representative to conduct erosion studies. At the University of Basel, Iserloh et al. [13] have calculated a kinetic energy of $5.8 \mathrm{~J} \cdot \mathrm{m}^{-2} \cdot \mathrm{mm}^{-1}$, which is much lower than the mean energies found in this study for Leon and Aveiro. 


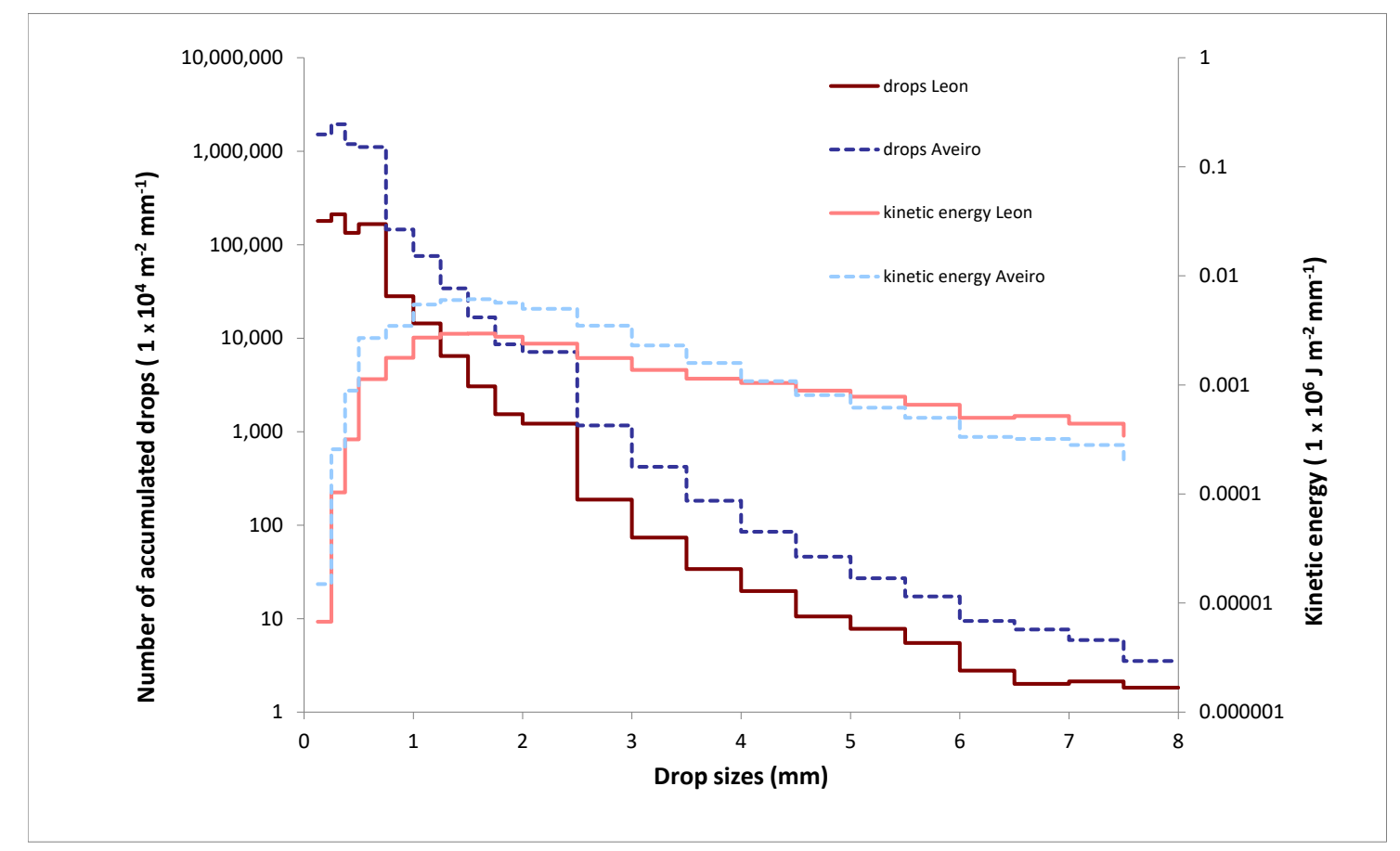

Figure 6. Total cumulative number of raindrops per unit area according to raindrop size and kinetic energy per unit area generated by the total of raindrops of each size during the period 20 May 2007 to 26 July 2008 in Leon, Spain, and Aveiro, Portugal.

In USLE (Universal Soil Loss Equation) the parameter $\mathrm{R}$ is the index of pluvial erosion $\left(\mathrm{J} \cdot \mathrm{m}^{-2} \cdot \mathrm{cm} \cdot\right.$ hour $\left.^{-1}\right)$, which is obtained with a theoretical equation who uses homogeneous periods of time raining and maximum intensities during the rain $\left(\mathrm{cm} \cdot \mathrm{hour}^{-1}\right)$. However, in this research, we are able to compare this parameter between two sites measuring it with the real drop size distribution. This is possibly due to the use of disdrometers which may measure the drop size distribution plus the speed of every drop. If we analyze the results with the use of weather types, in this article we can confirm that under a specific weather type there is a variability in the erosive capacity due to the different climate

\subsection{Types of Weather}

Figures 7-9 show that the most common type of weather according to Lamb's classification is anticyclonic, with a total of 87 days. Aveiro is influenced by its proximity to the sea and, therefore, morning fog and mist are very common. In contrast, Leon is much more continental and thus drier. The instruments have also detected short, mild morning rain events in Aveiro, but these barely reached a few $\mathrm{mm}$. This explains the high number of anticyclonic days with rainfall, although this is not usual (Figure 7). As a result, despite the large number of anticyclonic days with rain, the total amount of rainfall recorded was very small, and the sum of all the days with anticyclonic rain only accounted for $6 \%$ of the total (Figure 7).

In both Aveiro and Leon, the rainfall maintained a similar behavior with respect to types of weather. For example, for both sampling points, cyclonic weather (C) was associated with the highest cumulative rainfall, accounting for $216 \mathrm{~mm}$ in Aveiro (30\% of total cumulative rainfall) and $81 \mathrm{~mm}$ in Leon $(22 \%)$. In addition, rainy days predominated among westerly weather types $[6,31,36]$. This finding is expected, since the main rain fronts are westerly, entering from the Atlantic Ocean and subsequently crossing the Iberian Peninsula $[9,35,45]$. 


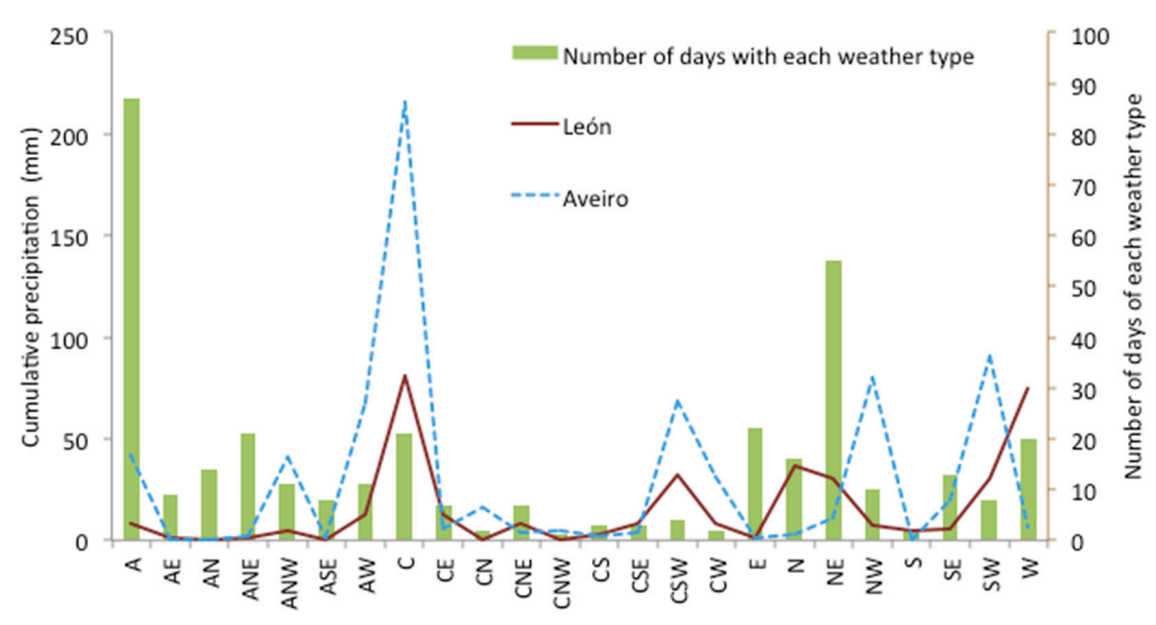

Figure 7. Frequency of weather types and total rainfall in Leon, Spain, and Aveiro, Portugal.

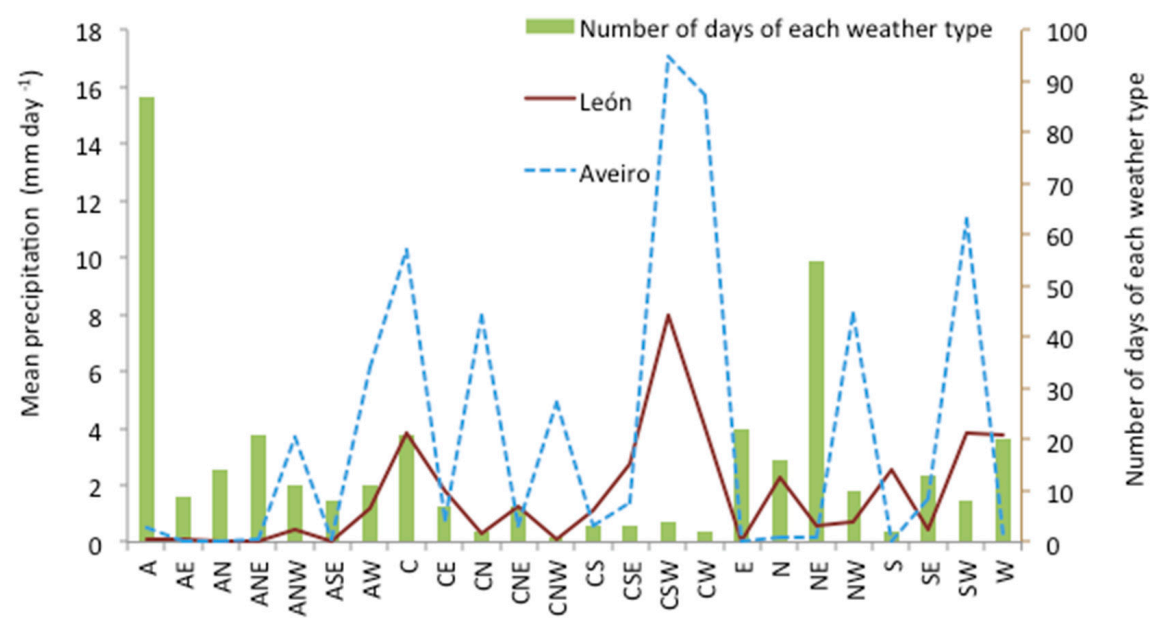

Figure 8. Frequency of weather types and mean daily rainfall in Leon, Spain, and Aveiro, Portugal.

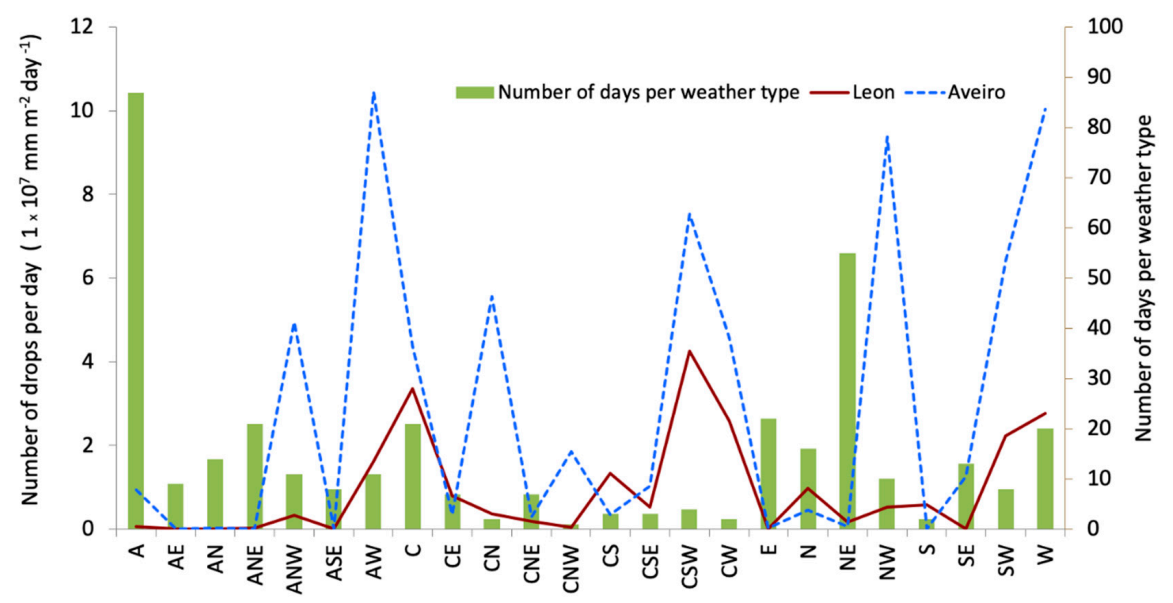

Figure 9. Frequency of weather types and number of daily raindrops per unit area recorded in Leon, Spain, and Aveiro, Portugal.

In Aveiro, the order from highest to lowest percentage of rainfall according to weather type was: C $(30 \%)>\operatorname{SW}(13 \%)>\mathrm{NW}(11 \%)>\mathrm{CSW}(10 \%)$, while for the same period in Leon it was C $(22 \%)>\mathrm{W}$ $(20 \%)>N(10 \%)>$ CSW $(9 \%)$. Rainfall thus appeared to show similar behavior in Leon and Aveiro for both cyclonic and anticyclonic weather types, but not for purely directional weather types. In addition, cyclonic and pure weather types were always observed to generate most rainfall. In fact, $68 \%$ of the 
total cumulative rainfall in Aveiro was recorded during westerly circulation weather types, and 56\% in Leon, even though the sum of westerly weather types only accounted for $20 \%$ of the total number of days. These results are consistent with research on the Iberian Peninsula using databases containing up to 53 years of data [6], with the results of a 44-year study conducted by Trigo and Dacamara [30], and the conclusions of a study by Fernandez-Gonzalez et al. [5], indicating that westerly weather generates most rainfall.

An analysis of mean daily rainfall by weather type has also indicated that a westerly direction together with cyclonic conditions increased the likelihood of rain. Consistent with this, more than $17 \mathrm{~mm}$ of mean daily rainfall were recorded in Aveiro and $8 \mathrm{~mm}$ in Leon under cyclonic south-westerly (CSW) conditions. This cyclonic situation usually corresponds to instability caused by a wet front from the Atlantic Ocean, which is one of the four scenarios proposed by Romero et al. [46] that generate heavy rainfall in the Iberian Peninsula.

Cyclonic westerly weather (CW) was also notable in terms of the average daily rainfall registered (Figure 8), accounting for $4 \mathrm{~mm}$ in Leon and $15.7 \mathrm{~mm}$ in Aveiro. The weather type that generated most cumulative rainfall (cyclonic, C) did not coincide with the type that generated the highest average daily rainfall (CSW) because it was a relatively common weather type, with 21 days in total (6\% of days) and therefore its average daily rainfall was lower than that of others with less cumulative rainfall but which occurred less frequently.

In contrast, the average rainfall for other weather types increased due to their low frequency of occurrence, implying division by a very low number of days, thus greatly increasing the average rainfall value. Such was the case of the cyclonic northerly weather type (CN), which generated $16 \mathrm{~mm}$ of cumulative rainfall in Aveiro (Figure 7), thus occupying the tenth place when weather types were ranked according to cumulative rainfall; but this same weather type occupies the fourth place $(8 \mathrm{~mm})$ when ranked according to average daily rainfall (Figure 8), because it is a very infrequent weather type (only $0.5 \%$ of the total number of days). In this case, the ranking of weather types from high to low average rainfall was similar in Aveiro and Leon, with CSW being the highest one in both cases, followed by CW, SW and C.

As regards the number of raindrops registered, Aveiro differed from Leon in having a higher number of raindrops per unit area during anticyclonic westerly weather (AW), which is not usually noted for rainfall (Figure 9). Westerly (W), north-westerly (NW) cyclonic south-westerly (CSW) and south-westerly (SW) weather types also featured prominently, with values higher than $10^{8}, 9.2 \times 10^{7}$, $7.5 \times 10^{7}$ and $6.3 \times 10^{7}$ raindrops per $\mathrm{m}^{-2}$, respectively. In Leon, however, cyclonic south-westerly (CSW) and cyclonic (C) weather types generated the highest number of raindrops, although in the reverse order of importance with respect to cumulative rainfall. These were followed by westerly (W) and south-westerly (SW) weather types, and thus CSW, W and SW types accounted for the highest number of raindrops at both locations, albeit with fewer raindrops in Leon than in Aveiro. For example, the number of raindrops registered in Leon was 56\% lower for cyclonic south-westerly (CSW) weather and $28 \%$ lower for westerly (W) weather.

An analysis of raindrop size spectra on rainy days according to weather type revealed that those with a westerly component presented the highest number of raindrops (AW, NW, W, CSW, SW and $\mathrm{CW})$. These all showed a similar spectrum as regards the gamma probability density function; most notably, there were 4 times more raindrops in Aveiro than in Leon per $\mathrm{m}^{2}$ (Figure 9).

Since the raindrop size spectra fit a gamma distribution [25], we have used gamma parameters (Table 4) to compare raindrop size distributions for different types of weather, and also to calculate the most frequent values or modes. The K-S test of goodness of fit has been applied to the gamma distributions for all the weather types, and a good fit was found in all cases for a significance level of $p<0.05$. 
Table 4. Mean values of $\alpha$ and $\beta$ parameters of the gamma probability density function of raindrop sizes, and mode ( $\mathrm{mm}$ ) by weather type in León, Spain, and Aveiro, Portugal, according to Lamb's classification.

\begin{tabular}{|c|c|c|c|c|c|c|c|}
\hline \multirow{2}{*}{\multicolumn{2}{|c|}{ Lamb Classification }} & \multicolumn{4}{|c|}{ Parameters } & \multirow{2}{*}{\multicolumn{2}{|c|}{ Mode (mm) }} \\
\hline & & \multicolumn{2}{|c|}{ Aveiro } & \multicolumn{2}{|c|}{ León } & & \\
\hline Weather Type & & $\beta\left(\mathrm{mm}^{-1}\right)$ & $\alpha$ & $\beta\left(\mathrm{mm}^{-1}\right)$ & $\alpha$ & Aveiro & León \\
\hline Anticyclonic & (A) & 9.46 & 3.07 & 4.40 & 1.86 & 0.22 & 0.19 \\
\hline Anticyclonic-easterly & $(\mathrm{AE})$ & 0.84 & 0.44 & 1.24 & 0.80 & 0 & 0 \\
\hline Anticyclonic-northerly & $(\mathrm{AN})$ & 4.35 & 1.45 & 2.79 & 0.97 & 0.10 & 0 \\
\hline Anticyclonic-northeasterly & (ANE) & 1.02 & 0.48 & 6.41 & 2.48 & 0 & 0.23 \\
\hline Anticyclonic-northwesterly & $(\mathrm{ANW})$ & 6.01 & 2.78 & 5.26 & 2.46 & 0.30 & 0.28 \\
\hline Anticyclonic-southerly & $(\mathrm{AS})$ & - & - & 2.46 & 0.97 & - & 0 \\
\hline Anticyciclonic southeasterly & (ASE) & 0.81 & 0.88 & 0.65 & 0.71 & 0 & 0 \\
\hline Anticyclonic-westerly & $(\mathrm{AW})$ & 12.01 & 4.61 & 5.82 & 2.12 & 0.30 & 0.19 \\
\hline Cyclonic & (C) & 3.47 & 1.74 & 5.42 & 2.27 & 0.21 & 0.23 \\
\hline Cyclonic-easterly & (CE) & 2.81 & 1.18 & 3.79 & 1.89 & 0.06 & 0.24 \\
\hline Cyclonic-northerly & $(\mathrm{CN})$ & 6.45 & 3.16 & 3.38 & 1.64 & 0.34 & 0.19 \\
\hline Cyclonic-northeasterly & (CNE) & 5.16 & 2.70 & 1.52 & 0.78 & 0.33 & 0 \\
\hline Cyclonic-northwesterly & $(\mathrm{CNW})$ & 4.92 & 2.96 & 7.53 & 3.96 & 0.40 & 0.39 \\
\hline Cyclonic-southerly & $(\mathrm{CS})$ & 5.76 & 2.91 & 9.49 & 4.03 & 0.33 & 0.32 \\
\hline Cyclonic-southeasterly & (CSE) & 4.08 & 1.68 & 2.39 & 1.35 & 0.17 & 0.14 \\
\hline Cyclonic-southwesterly & (CSW) & 3.91 & 1.96 & 5.56 & 2.90 & 0.25 & 0.34 \\
\hline Cyclonic-westerly & $(\mathrm{CW})$ & 3.03 & 1.63 & 4.91 & 2.16 & 0.21 & 0.24 \\
\hline Northerly & $(\mathrm{N})$ & 20.77 & 4.75 & 3.39 & 1.79 & 0.18 & 0.23 \\
\hline Northeasterly & $(\mathrm{NE})$ & 2.74 & 1.17 & 2.30 & 0.97 & 0.06 & 0 \\
\hline Northwesterly & (NW) & 9.02 & 3.84 & 4.07 & 1.89 & 0.32 & 0.22 \\
\hline Southerly & (S) & 1.44 & 0.89 & 2.32 & 1.27 & 0 & 0.12 \\
\hline Southeasterly & (SE) & 10.60 & 3.73 & 0.38 & 0.39 & 0.26 & 0 \\
\hline Southwesterly & (SW) & 4.43 & 2.07 & 4.16 & 1.90 & 0.24 & 0.22 \\
\hline Westerly & $(W)$ & 4.48 & 2.30 & 5.41 & 2.47 & 0.29 & 0.27 \\
\hline
\end{tabular}

Table 4 shows that both locations generally present very similar parameter values for the gamma distribution function of the size spectrum, except for the weather types that include an easterly component, such as south-easterly (SE), or easterly and anticyclonic south-westerly (E and ASW), with no rain, and which are not shown in the table. In easterly weather types, the mode depended on the location: for CNE and SE types, the mode was about $0.3 \mathrm{~mm}$ higher in Aveiro than in Leon. For ANE and CE types, the mode was $0.2 \mathrm{~mm}$ higher in Leon, and very close to 0 in Aveiro, representing quasi-exponential distribution values. In all other cases, the difference was less than $0.15 \mathrm{~mm}$ (and for $70 \%$ of weather types it was less than $0.1 \mathrm{~mm}$ ).

In Aveiro, $\alpha$ values ranged between 0.44 for $\mathrm{AE}$ and 4.75 for $\mathrm{N}$, whereas the dispersion of $\alpha$ values in Leon was somewhat lower, from 0.39 for SE to 4.03 for CS.

In both sites, the raindrop size distributions corresponding to AE, ASE, NE and S weather types are the closest to an exponential distribution. However, when only the distributions corresponding to weather types in Leon are considered, besides the weather types already mentioned, distributions corresponding to $\mathrm{AN}, \mathrm{CNE}$ also present a quasi-exponential distribution.

As shown in Table 5, the momentum of the rainfall follows a similar pattern to the kinetic energy, except for the case of CSE. Table 5 shows the kinetic energy and the linear momentum of the drops, which are very important variables in the estimation of soil erosion by rainfall. The kinetic energy and the momentum (Table 5) have a similar spectrum in Aveiro and Leon, except for the moment of the CSE in the case of Leon. The general pattern in both sites shows that the cyclonic weather types are the most energetic and the pure weather types range second. In both locations, the cyclonic westerly weather type is the most energetic one. However, there are weather types that behave differently in both locations; for example, the weather types cyclonic (C) and westerly $(\mathrm{W})$ produce a higher impact on the soil in Aveiro, while in Leon the weather types from the south (S) and the cyclonic south-easterly (CSE) and cyclonic westerly (CSW) have more energy than the rest of the weather types. 
Table 5. Kinetic energy and momentum by weather type for Aveiro and Leon in the study period. The weather types without data (anticyclonic south (AS), anticyclonic south-westerly (ASW) and E) have been removed.

\begin{tabular}{|c|c|c|c|c|c|c|c|}
\hline \multirow{3}{*}{ Weather Type } & \multirow{3}{*}{$\begin{array}{c}\text { Number of } \\
\text { Days }\end{array}$} & \multicolumn{3}{|c|}{ Aveiro } & \multicolumn{3}{|c|}{ Leon } \\
\hline & & $\begin{array}{c}\text { Kinetic Energy } \\
\text { per Day }\end{array}$ & Kinetic Energy & Momentum & $\begin{array}{l}\text { Kinetic Energy } \\
\text { per Day }\end{array}$ & Kinetic Energy & Momentum \\
\hline & & $\mathrm{J} /\left(\mathrm{m}^{2}\right.$ day $)$ & $\mathrm{J} / \mathrm{m}^{2}$ & $\mathrm{~kg} \mathrm{~m} / \mathrm{s}$ & $\mathrm{J} /\left(\mathrm{m}^{2}\right.$ day $)$ & $\mathrm{J} / \mathrm{m}^{2}$ & $\mathrm{~kg} \mathrm{~m} / \mathrm{s}$ \\
\hline \multicolumn{8}{|l|}{ Anticyclonic } \\
\hline A & 87 & 0.02 & 1.95 & 1.31 & 0.02 & 1.65 & 0.72 \\
\hline $\mathrm{AE}$ & 9 & 0.17 & 1.55 & 0.38 & 0.35 & 3.11 & 0.80 \\
\hline AN & 14 & 0.01 & 0.14 & 0.06 & 0.57 & 7.99 & 2.92 \\
\hline ANE & 21 & 0.10 & 2.18 & 0.55 & 0.01 & 0.17 & 0.09 \\
\hline ANW & 11 & 1.87 & 20.57 & 10.01 & 0.26 & 2.88 & 1.32 \\
\hline ASE & 8 & 0.57 & 4.55 & 1.07 & 0.12 & 0.97 & 0.23 \\
\hline $\mathrm{AW}$ & 11 & 2.09 & 22.98 & 15.92 & 0.76 & 8.38 & 4.32 \\
\hline \multicolumn{8}{|l|}{ Cyclonic: } \\
\hline $\mathrm{C}$ & 21 & 6.01 & 126.28 & 47.63 & 1.22 & 25.71 & 12.33 \\
\hline CE & 7 & 1.91 & 13.35 & 4.75 & 3.76 & 26.35 & 10.32 \\
\hline $\mathrm{CN}$ & 2 & 27.36 & 54.71 & 26.87 & 5.81 & 11.62 & 4.36 \\
\hline $\mathrm{CNE}$ & 7 & 0.83 & 5.83 & 2.56 & 3.76 & 26.31 & 7.30 \\
\hline $\mathrm{CNW}$ & 1 & 50.49 & 50.49 & 20.84 & 5.17 & 5.17 & 2.62 \\
\hline CS & 3 & 1.46 & 4.39 & 2.04 & 1.63 & 4.88 & 2.95 \\
\hline CSE & 3 & 4.29 & 12.86 & 5.44 & 12.66 & 37.98 & 12.11 \\
\hline CSW & 4 & 43.03 & 172.12 & 68.25 & 15.72 & 62.89 & 28.49 \\
\hline $\mathrm{CW}$ & 2 & 126.77 & 253.55 & 89.22 & 17.13 & 34.27 & 15.50 \\
\hline \multicolumn{8}{|l|}{ Pure: } \\
\hline $\mathrm{N}$ & 16 & 0.00 & 0.04 & 0.05 & 2.30 & 36.80 & 13.59 \\
\hline NE & 55 & 0.05 & 2.77 & 0.97 & 0.12 & 6.69 & 2.19 \\
\hline NW & 10 & 4.46 & 44.59 & 26.42 & 2.63 & 26.26 & 10.79 \\
\hline $\mathrm{S}$ & 2 & 0.39 & 0.78 & 0.21 & 20.97 & 41.95 & 13.29 \\
\hline SE & 13 & 0.11 & 1.42 & 0.97 & 0.91 & 11.89 & 2.70 \\
\hline SW & 8 & 12.25 & 98.02 & 41.72 & 3.98 & 31.80 & 13.24 \\
\hline W & 20 & 8.94 & 178.77 & 74.55 & 1.16 & 23.29 & 10.88 \\
\hline
\end{tabular}

This difference may be due to the fact that the fronts coming from the west to Leon have first crossed an orographic barrier in Serra da tras-os Montes e alto Douro and Serra da-Estrela, and reach Leon with a smaller amount of water (Table 5).

From the five most energetic weather types in the whole study period in Aveiro and Leon, only CSW and CW occur in both places (both from the west). In Aveiro, the other three most energetic weather types are: 2 westerlies (W and SW) and C, while in Leon, the rest are S, CSE and N.

Concerning the daily kinetic energy, again CW and CSW are the types with a higher value, but, in this case, $\mathrm{CN}$ also stands out in both sites (it was registered only in two rain days, but the raindrops in both days were very energetic). Except the $\mathrm{CN}$, all the most energetic weather types in Aveiro have a westerly component (CW, CNW, CSW and SW), but in Leon, they do not (S and CSE).

In Aveiro the precipitation volume is larger than in Leon, so the energy is also higher. Indeed, the weather types from Aveiro are rainier than in Leon except AE; AN; CE; CNE; CS; CSE; N; NE; S; $\mathrm{SE}$. This means that the cyclonic weather types are usually rainier in Leon than in Aveiro only when coming from the east (CE, CNE, CSE) or south (CS). Concerning the purely directional types, they are rainier in Aveiro than in Leon only when coming from the west.

\section{Conclusions}

We have compared rainfall in Aveiro, Portugal, and Leon, Spain, two cities located $330 \mathrm{~km}$ apart with oceanic and continental climates, respectively, over a study period of more than one year. Applying a new methodology of comparison, we can confirm that the classification on Lamb weather types cannot substitute the rainfall parameters measure with other instruments on models of erosion, because under the same weather type we may find differences between the characteristics of rainfall more important for erosion measured in each climate.

Our results indicate that Aveiro, the city with an oceanic climate, experiences heavier and more abundant rainfall, with a higher number of raindrops per $\mathrm{m}^{2}$ and a longer duration of rain events (10 min longer on average). In addition, the kinetic energy and linear momentum of rainfall in Aveiro 
on average doubled that of Leon. Mean raindrop size was $0.45 \mathrm{~mm}$ in Aveiro, and slightly lower, $0.37 \mathrm{~mm}$, in Leon, consistent with momentum and kinetic energy. This is very important due to the close link between kinetic energy and erosion reflected in the literature.

This study of weather types has confirmed that westerly types present the highest probability of rain in both Aveiro and Leon. Of particular importance was the cyclonic south-westerly weather (CSW), with almost $17 \mathrm{~mm}$ of mean daily rainfall in Aveiro and about $8 \mathrm{~mm}$ in Leon. In general, cyclonic and pure weather types generate most rainfall in both locations.

When we fitted the raindrop size spectrum to the gamma probability density, we found that the gamma distribution parameters for each type of weather were independent of the study zone (Aveiro or Leon), except for weather with an easterly component, which varied slightly more. For these types, the mode depended on the location. For CNE and SE, the mode was about $0.3 \mathrm{~mm}$ higher in Aveiro than in Leon. For ANE and EC, the mode was $0.2 \mathrm{~mm}$ higher in Leon. In all other cases, the difference was less than $0.15 \mathrm{~mm}$ (and for $70 \%$ of weather types it was less than $0.1 \mathrm{~mm}$ ).

Concerning the analysis of which weather types may have a bigger impact on erosion, it can be seen that two of the five weather types with higher kinetic energy and momentum coincide in both locations (CW and CSW), while the other three more energetic weather types depend on the site. In Aveiro the component from the west seems to have a bigger influence, whereas in Leon the component from the south seems to have more erosive power.

Author Contributions: Conceptualization: M.F.-R. and R.F.; methodology, A.C.; software M.F.-R.; validation, M.F.-R. and C.P; formal analysis, M.F.-R.; investigation, M.F.-R. and A.M.C.; resources, R.F.; Writing-Original draft preparation, M.F.-R., E.M.; Writing-Review and editing, M.F.-R., R.F. and E.M.; visualization, A.M.C.; supervision, A.C. and C.P. All authors have read and agreed to the published version of the manuscript.

Funding: This study was partially supported by the Spanish Ministry of Science and Innovation (Grants TEC2014-57821-R and CGL2014-52556-R). María Fernández-Raga acknowledges a post-doctoral grant from Spanish Ministry of Science and Innovation (Grant CAS16/00385) to carry out the research.

Acknowledgments: The authors are also grateful to Noelia Ramon for revising the English language of the final version of this paper. We also are very grateful to Jan Jacob Keyzer for his help in looking for a place to set the disdrometer in Aveiro and also his help to install and maintain this disdrometer during the time of the study.

Conflicts of Interest: The authors declare no conflict of interest.

\section{References}

1. Paschalidou, A.K.; Psistaki, K.; Charalampopoulos, A.; Vokou, D.; Kassomenos, P.; Damialis, A. Identifying patterns of airborne pollen distribution using a synoptic climatology approach. Sci. Total Environ. 2020, 714, 136625. [CrossRef]

2. Rodrigues, M.; González-Hidalgo, J.C.; Peña-Angulo, D.; Jiménez-Ruano, A. Identifying wildfire-prone atmospheric circulation weather types on mainland Spain. Agric. For. Meteorol. 2019, 264, 92-103. [CrossRef]

3. Peña-Angulo, D.; Nadal-Romero, E.; González-Hidalgo, J.C.; Albaladejo, J.; Andreu, V.; Bagarello, V.; Barhi, H.; Batalla, R.J.; Bernal, S.; Bienes, R.; et al. Spatial variability of the relationships of runoff and sediment yield with weather types throughout the Mediterranean basin. J. Hydrol. 2019, 571, 390-405. [CrossRef]

4. Zwiebel, J.; Van Baelen, J.; Anquetin, S.; Pointin, Y.; Boudevillain, B. Impacts of orography and rain intensity on rainfall structure. The case of the HyMeX IOP7a event. Q. J. R. Meteorol. Soc. 2016, 142, 310-319. [CrossRef]

5. Fernandez-Gonzalez, S.; del Rio, S.; Castro, A.; Penas, A.; Fernandez-Raga, M.; Calvo, A.; Fraile, R. Connection between NAO, weather types and precipitation in Leon, Spain (1948-2008). Int. J. Climatol. 2012, 32, 2181-2196. [CrossRef]

6. Ramos, A.M.; Cortesi, N.; Trigo, R.M. Circulation weather types and spatial variability of daily precipitation in the Iberian Peninsula. Front. Earth Sci. 2014, 2, 1-17. [CrossRef]

7. Gimeno, L.; Nieto, R.; Trigo, R.M.; Vicente-Serrano, S.M.; Lopez-Moreno, J.I. Where does the Iberian Peninsula moisture come from an answer based on a lagrangian approach. J. Hydrometeorol. 2010, 11, 421-436. [CrossRef] 
8. Trigo, R.M.; Pozo-Vazquez, D.; Osborn, T.J.; Castro-Diez, Y.; Gamiz-Fortis, S.; Esteban-Parra, M.J. North Atlantic Oscillation influence on precipitation, river flow and water resources in the Iberian Peninsula. Int. J. Climatol. 2004, 24, 925-944. [CrossRef]

9. Cortesi, N.; Trigo, R.M.; Gonzalez-Hidalgo, J.C.; Ramos, A.M. Modelling monthly precipitation with circulation weather types for a dense net-work of stations over Iberia. Hydrol. Earth. Syst. Sci. 2013, 17, 665-678. [CrossRef]

10. De Luis, M.; Brunetti, M.; Gonzalez-Hidalgo, J.; Longares, L.; Martin-Vide, J. Changes in seasonal precipitation in the Iberian Peninsula during 1946-2005. Glob. Planet. Chang. 2010, 74, 27-33. [CrossRef]

11. Wetterzentrale. Available online: http://www.wetterzentrale.de (accessed on 31 October 2019).

12. Angulo-Martinez, M.; Begueria, S.; Navas, A.; Machin, J. Splash erosion under natural rainfall on three soil types in NE Spain. Geomorphology 2012, 175-176, 38-44. [CrossRef]

13. Iserloh, T.; Fister, W.; Seeger, M.; Willger, H.; Ries, J. A small portable rainfall simulator for reproducible experiments on soil erosion. Soil Tillage Res. 2012, 124, 131-137. [CrossRef]

14. Van Dijk, A.I.J.M.; Bruijnzeel, L.A.; Rosewell, C.J. Rainfall intensity-kinetic energy relationships: A critical literature appraisal. J. Hydrol. 2002, 261, 1-23. [CrossRef]

15. Thurai, M.; Bringi, V.; Manic, A.; Sekeljic, N.; Notaros, B. Investigating raindrop shapes, oscillation modes, and implications for radio wave propagation. Radio Sci. 2014, 49, 921-932. [CrossRef]

16. Raupach, T.H.; Berne, A. Spatial interpolation of experimental raindrop size distribution spectra. Q. J.R. Meteorol. Soc. 2016, 142, 125-137. [CrossRef]

17. Angulo-Martinez, M.; Begueria, S.; Kysely, J. Use of disdrometer data to evaluate the relationship of rainfall kinetic energy and intensity (KE-I). Sci. Total Environ. 2016, 568, 83-94. [CrossRef]

18. Sanchez-Moreno, J.F.; Mannaerts, C.M.; Jetten, V.; Löffler-Mang, M. Rainfall kinetic energy-intensity and rainfall momentum-intensity relationships for Cape Verde. J. Hydrol. 2012, 454-455, 31-40. [CrossRef]

19. Belo-Pereira, M.; Dutra, E.; Viterbo, P. Evaluation of global precipitation data sets over the Iberian Peninsula. J. Geophys. Res. Atmos. 2011, 116, 1-16. [CrossRef]

20. Del Rio, S.; Herrero, L.; Fraile, R.; Penas, A. Spatial distribution of recent rainfall trends in Spain (1961-2006). Int. J. Climatol. 2011, 31, 656-667. [CrossRef]

21. Michailidou, C.; Maheras, P.; Arseni-Papadimititriou, A.; Kolyva-Machera, F.; Anagnostopoulou, C. A study of weather types at Athens and Thessaloniki and their relationship to circulation types for the cold-wet period, part II: Discriminant analysis. Theor. Appl. Climatol. 2009, 97, 179-194. [CrossRef]

22. Paredes, D.; Trigo, R.; Garcia-Herrera, R.; Trigo, I. Understanding precipitation changes in Iberia in early spring: Weather typing and storm-tracking approaches. J. Hydrometeorol. 2006, 7, 101-113. [CrossRef]

23. Meteopt. Metorology Service of Portugal. 2015. Available online: http://www.meteopt.com/forum/topico/ diversidade-climatica.4708/page-51 (accessed on 18 November 2015).

24. Provincial council Leon, S. Clima of Leon. Diputacion de Leon. 2015. Available online: http://www.dipuleon. es/frontdipuleon/frontDipuleonAction.do?action=viewCategory\&categoryName=El+clima\&id=27631 (accessed on 24 December 2015).

25. Fernandez-Raga, M.M.; Castro, A.; Marcos, E.; Palencia, C.; Fraile, R. Weather types and rainfall microstructure in Leon, Spain. Int. J. Climatol. 2016. [CrossRef]

26. Aena. Tiempo Aeropuerto de Leon. 2015. Available online: http://www.aena.es/csee/satellite/ AeropuertoLeon/es/Page/1132835453229/ (accessed on 18 November 2015).

27. Font, I. Climatologia de España y Portugal; Ediciones Universidad de Salamanca: Salamanca, Spain, 2000; p. 424.

28. Snirh. Sistema Nacional de Informacion de Recursos Hidricos de Portugal. 2010. Available online: http://snirh.pt (accessed on 18 November 2015).

29. Fernandez-Raga, M.; Castro, A.; Palencia, C.; Calvo, A.I.; Fraile, R. Rain events on 22 October 2006 in Leon (Spain): Drop size spectra. Atmos. Res. 2009, 93, 619-635. [CrossRef]

30. Trigo, R.Y.; Dacamara, C. Circulation weather types and their influence on the precipitation regime in Portugal. Int. J. Climatol. 2000, 20, 1559-1581. [CrossRef]

31. Fernandez-Raga, M.; Fraile, R.; Keizer, J.J.; Teijeiro, M.E.V.; Castro, A.; Palencia, C.; Calvo, A.I.; Koenders, J.; Marques, R.L.D. The kinetic energy of rain measured with an optical disdrometer: An application to splash erosion. Atmos. Res. 2010, 96, 225-240. [CrossRef] 
32. Jones, P.; Osborn, T.; Harpham, C.; Briffa, K. The development of Lamb weather types: From subjective analysis of weather charts to objective approaches using reanalyses. Weather 2014, 69, 128-132. [CrossRef]

33. Lamb, H. British Isles Weather types and a register of daily sequence of circulation patterns: 1861-1971. Geophys. Mem. 1972, 116, 85.

34. Jenkinson, A.; Collison, F. An initial climatology of gales over the North sea. In Synoptic Climatology Branch Memorandum; Meteorological Office: London, UK, 1977.

35. Cortesi, N.; Gonzalez-Hidalgo, C.; Trigo, R.; Ramos, A.M. Weather types and spatial variability of precipitation in the Iberian Peninsula. Int. J. Climatol. 2014, 34, 2661-2677. [CrossRef]

36. Fernandez-Raga, M. Estudio de la Precipitacion Mediante Disdrometros. Una Aplicacion Particular: Erosion por Salpicadura. Ph.D. Thesis, University of León, León, Spain, 2012; 307p.

37. Silva, I.; de Oliveira, J.; Fontes, L.; Arraes, F. Frequency distribution of rainfall for the South-Central region of Ceara, Brazil. Rev. Cienc. Agron. 2013, 44, 481-487. [CrossRef]

38. Marques, R.; Mello, C.; Silva, A.; Franco, C.; Oliveira, A. Performance of the probability distribution models applied to heavy rainfall daily events.Desempenho de distribuições de probabilidades aplicadas a eventos extremos de precipitação diaria. Cienc. E Agrotecnologia 2014, 38, 335-342. [CrossRef]

39. Yu, N.; Delrieu, G.; Boudevillain, B.; Hazenberg, P.; Uijlenhoet, R. Unified Formulation of Single- and Multimoment Normalizations of the Raindrop Size Distribution Based on the Gamma Probability Density Function. J. Appl. Meteorol. Climatol. 2014, 53, 166-179. [CrossRef]

40. Gonzalez-Pola, C.M. Variabilidad Climatica Oceanica en la Region Sureste del Golfo de Vizcaya. Ph.D. Thesis, Instituto Español de Oceanografia, Madrid, Spain, 2008; 192p.

41. Adirosi, E.; Baldini, L.; Lombardoc, F.; Russob, F.; Napolitano, F.; Volpic, E.; Tokay, A. Comparison of different fittings of drop spectra for rainfall retrievals. Adv. Water Resour. 2015, 83, 55-67. [CrossRef]

42. Mariani, L.; Jimenez, J.J.; Torres, E.A.; Amezquita, E.; Decaens, T. Rainfall impact effects on ageing casts of a tropical anecic earthworm. Eur. J. Soil Sci. 2007, 58, 1525-1534. [CrossRef]

43. Roldan Soriano, M. Estimacion de la energia cinetica de la lluvia a partir de la precipitacion diaria. Nueva metodologia para el calculo del factor "R". Aplicacion en España. In Congresos Forestales; Junta de Castilla y Leon, Avila: Valladolid, Spain, 2009; pp. 1-17, ISBN 9878493685461.

44. Van Dijk, A.I.J.M.; Meesters, A.G.C.A.; Bruijnzeel, L.A. Exponential distribution theory applied to splash detachment and transports experiments. J. Appl. Meteor. 2002, 18, 654-660. [CrossRef]

45. Lorenzo, M.; Iglesias, I.; Taboada, J.; Gomez-Gesteira, M. Relationship between monthly rainfall in northwest Iberian Peninsula and North Atlantic sea surface temperature. Int. J. Climatol. 2010, 30, 980-990. [CrossRef]

46. Romero, R.; Sumner, G.; Ramis, C.; Genoves, A. A classification of the atmospheric circulation patterns producing significant daily rainfall in the Spanish mediterranean area. Int. J. Climatol. 1999, 19, 765-785. [CrossRef]

(C) 2020 by the authors. Licensee MDPI, Basel, Switzerland. This article is an open access article distributed under the terms and conditions of the Creative Commons Attribution (CC BY) license (http://creativecommons.org/licenses/by/4.0/). 